\title{
The Adaptation Strategy in Translating Culture-bound Expressions Involved in The Dubbed Version of Monsters Inc. Movie for children \\ Shaimaa Ahmed Ibrahim
}

\begin{abstract}
This study focuses on adaptation as one of solution-oriented approaches to the problems raised by the gap between two different cultures. In other words, adaptation is a free translation strategy that is employed to translate culture-bound elements appeared in the Arabic dubbing of Monsters, Inc. movie for children. Adaptation seeks to culturally and linguistically suit the target readers/audiences. For the purpose of the current study, attention is paid to dubbing movies primarily targeted children. So, a widely watched American animated movie, namely, Monsters, Inc., dubbed into Egyptian Arabic dialect, is examined in light of adaptation as a translation strategy. This research aims at showing how the different procedures of adaptation are utilized during the process of dubbing. Also, it highlights the effective contribution of adaptation to the Arabic dubbed version of Monsters, Inc. through transferring the cultural terms that appeared in the English version.
\end{abstract} Keywords: Adaptation, domestication, dubbing, culture, idioms, and Monsters, Inc.

(*) This paper is part of an M.A. thesis entitled : The Adaptation Strategy in Translating Children's Movies: A Study of Dubbing "Monsters Inc." from English into Arabic, Supervised by Prof. Bahaa el Deen M. Mazeed - Faculty of Al- Alsun, Sohag University \& Dr. Ismail Abdel-Ghani Ahmed - Faculty of Arts, Sohag University. 


\section{Abstract}

Phonetic Symbols Used in the Phonemic Transcription of Arabic

\section{Introduction}

2. Research Questions

\section{Theoretical Framework}

3. 1. Bastin's Model of Adaptation

\section{Methodology}

4.1. Data Collection

4.2. Data Analysis and Discussion

\section{Conclusion}

\section{References}

Phonetic Symbols Used in the Phonemic Transcription of Arabic

The following phonemic symbols are used in transcribing the Arabic data. They are listed in the "Handbook of the International Phonetic Association" (1999, pp. 51:52).

\begin{tabular}{|c|c|c|}
\hline \multicolumn{2}{|c|}{ Consonants } \\
\hline \multicolumn{2}{|c|}{ Symbols } & Descriptions \\
\hline$/ ? /$ & $\hookrightarrow$ & Voiceless glottal stop \\
\hline$/ \mathrm{b} /$ & + & Voiced bilabial stop \\
\hline$/ \mathrm{t} /$ & $\bullet$ & Voiceless alveolar stop \\
\hline$/ \theta /$ & $\doteq$ & Voiceless dental fricative \\
\hline$/ \mathrm{j} /$ & $\subsetneq$ & Voiced palatal fricative \\
\hline$/ \mathrm{g} /$ & $\tau$ & Voiced velar stop \\
\hline$/ \mathrm{h} /$ & $\tau$ & Voiceless pharyngeal fricative \\
\hline$/ \mathrm{x} /$ & $\tau$ & Voiceless velar fricative \\
\hline & & $\mathbf{4}$ \\
\hline
\end{tabular}


Bulletin of The Faculty of Arts, Vol. (52), No. (2) July 2019

\begin{tabular}{|c|c|c|}
\hline$/ \mathrm{d} /$ & د & Voiced alveolar stop \\
\hline /ð/ & j & Voiced dental fricative \\
\hline$/ \mathrm{r} /$ & $\jmath$ & Alveolar trill \\
\hline $\mid \mathrm{z} /$ & j & Voiced alveolar fricative \\
\hline /s/ & 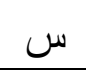 & Voiceless alveolar fricative \\
\hline$/ \check{\mathrm{S}} /$ & ش & Voiceless palate-alveolar fricative \\
\hline /s/ & 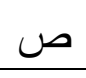 & Voiceless velarized alveolar fricative \\
\hline$/ \underline{\mathrm{d}} /$ & ض & Voiced velarized alveolar stop \\
\hline$/ \underline{\mathrm{t}} /$ & b & Voiceless velarized alveolar stop \\
\hline I $\underline{z} \mid$ & ظ & Voiced velarized dental fricative \\
\hline$/ ؟ /$ & $\varepsilon$ & Voiced pharyngeal fricative \\
\hline $\operatorname{lgh} /$ & $\dot{\varepsilon}$ & Voiced uvular fricative \\
\hline /f/ & ف & Voiceless labio-dental fricative \\
\hline /q/ & 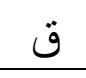 & Voiceless uvular stop \\
\hline$/ \mathrm{k} /$ & 5 & Voiceless velar stop \\
\hline /1/ & 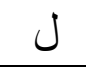 & Voiced alveolar lateral \\
\hline$/ \mathrm{m} /$ & 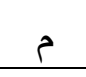 & Voiced bilabial nasal \\
\hline$/ \mathrm{n} /$ & ن & Voiced alveolar nasal \\
\hline$/ \mathrm{h} /$ & ه & Voiceless glottal fricative \\
\hline$/ \mathrm{w} /$ & 9 & Voiced bilabial glide \\
\hline /y/ & 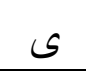 & Voiced palatal glide \\
\hline \multicolumn{3}{|r|}{ Short vowels } \\
\hline /a/ & 5 & Short close front vowel \\
\hline /i/ & \& & Short half-close central vowel \\
\hline$/ \mathrm{u} /$ & ? & Short close back vowel \\
\hline \multicolumn{3}{|r|}{ Long Vowels } \\
\hline /aa/ & 1 & Long close front vowel \\
\hline
\end{tabular}




\begin{tabular}{|c|c|c|}
\hline /ii/ & L & Long half-close central vowel \\
\hline /uu/ & $و$ & Long close back vowel \\
\hline
\end{tabular}

Every transcription is written between two slashes / / and is preceded with an Arabic translation.

\section{Introduction}

Translation was and still a subject of controversy, both as a process or a product; a process with no end and a product with unlimited translations. The subject matter of translation is not only about carrying the meaning of words from one language into another. As stated by Bassnett (2002), it is "an act of both inter-cultural and inter-temporal communication" (p. 9). Culture cannot be separated from translation. Translation is a main factor of linking different cultures and narrowing the gap between them. It is also a means of communication through different cultures. There are a number of factors that should be considered during the process of translation other than taking care of transmitting the meaning of every single word from language to another. In this regard, House (2009) claims that "translation is not only a linguistic act, but it is also a cultural one; i.e., an act of communication across cultures" (p. 69). Therefore, linguistic competence is not the only or main quality the translator should have. Cultural translation, according to Nida and Taber (1982), is "a translation in which the content of the message is changed to conform to the receptor culture in some way, and/or in which information is introduced which is not linguistically implicit in the original" (p.199). 
Culture has multiple forms. Movies are a reflection of the cultures from which they come. Monsters Inc. is one of the movies that are lodging so firmly in people's minds. By investigating the corpus at hand, it could be said that a large number of cultural references were being observed. To put it simply, movies imported from the West are inevitably being expected to contain various cultural references that are possibly not accepted or easily understood in such conservative Arab and Islamic societies. Here comes the vital role of adaptation in narrowing the gap between cultures opposed to each other. That is, the role being played by adaptation is conceptualized in changing these unacceptable references in order to be approachable to the culture of the target audiences in the Arab world. To conclude, cultures can be introduced visually and aurally. Thus, films can be a tremendously influential vehicle for transferring a different set of thoughts and values.

\section{Research Questions:}

1- How culture-bound expressions involved in Monsters, Inc are treated and presented?

2- What are the procedures of adaptation which have been mostly focused in translating the cultural references appeared in Monsters, Inc. particularly during the process of dubbing?

\section{Theoretical Framework}

\subsection{Bastin's Model of Adaptation}

Adaptation is the subject matter of the current study. Therefore, this section is wholly dedicated for investigating 
various definitions of adaptation from a translational perspective, with special emphasis on Bastin's (2009) model on which the study mainly depends; investigating how adaptation and its several procedures play purposely an effective role in solving the problems caused by the transmission process between different language cultures. These various procedures are made to serve a good understanding for the target text readers or audiences and, to some extent, be loyal to them. It can be said that the main purpose of adaptation is starkly summarized by Sanders (2006) as "adaptation can constitute a simple attempt to make texts relevant or easily comprehensible to new audiences and readerships via the processes of proximation and updating" (p.

19). In addition, Bastin (2015), sees adaptation as

A translational decision, an action taken by a translator (or adapter) in a particular situation. This action is needed because of the lack of linguistic and cultural correspondence between ST and TT [...]. It is therefore an action aimed at deviating from ST literality for various purposes:

1- To preserve ST meaning or cultural aspects

2- $\quad$ To facilitate the reader's understanding (to paraphrase, to add para-text such as a preamble to the reader, footnotes or a glossary)

3- To appropriate the ST and manipulate it for personal reasons. For example: appropriation, imitation or parody and pastiche (pp. 76-77). 
There are a number of various procedures that can be tackled by the translator in order to produce a TT that is expected to be accepted in the TLC. In other words, adaptation, according to Bastin (2009), can be applied to texts by utilizing a number of many different procedures as listed below:

- Transcription of the original: word for word reproduction of part of the text in the original language, usually accompanied by a literal translation.

- Omission: the elimination or implication of part of the text.

- Expansion: the addition or explication of source information, either in the main body or in a foreword, footnotes or a glossary.

- Exoticism: the substitution of stretches of slang, dialect, nonsense words, etc... in the original text by rough equivalents in the target language (sometimes marked by italics or underlining)

- Updating: the replacement of outdated or obscure information by modern equivalents.

- Situational or cultural adequacy: the reception of a context that is more familiar or culturally appropriate from the target reader's perspective than the one used in the original.

- Creation: a more global replacement of the original text with a text that preserves only the essential message/ideas/functions of the original (pp. 4:5). 


\section{Methodology}

This section is wholly dedicated to the procedures for collecting data, mentioning the corpus, and giving a general description of it. Moreover, the tools utilized during the analysis process of data are briefly explained.

\subsection{Data Collection}

This section focuses on the procedures for collecting data. For the purpose of the present study, the data are introduced in a widely known movie, namely, Monsters Inc. which was dubbed from English into colloquial Egyptian Arabic. The analysis shows how different procedures for adaptation are employed during the process of dubbing in transferring different cultural expressions. Moreover, the reasons for resorting to adaptation are clearly explained.

\subsection{Data Analysis and Discussion}

\subsubsection{Cultural or Situational adequacy}

Example1

Mike: OH, WE'RE EASY PREY, MY FRIEND-- EASY PREY.

\section{WE'RE SITTING TARGETS.}

\section{مارد وشوشني: إحنا صيدة سهلة يا حبيبي لقطة خييتنا تقيلة}

The context of the source utterance is rendered into familiar cultural expressions to the target audiences. The expression (لقطة خيتنا تقبلة' /luktaxibtnaatqyla/ is the colloquial Egyptian Arabic equivalent of 'we are sitting targets'. The word 'قطة' /lukta/ means 'looking for a catch' and 'خيبتنا تقيلة' /xibtnaatqyla/ denotes disappointment because of something bad one expects to happen. The translator joined the two previous 
common Egyptian expressions that cognitively convey the sense of the original.

Example 2

Mike: SULLEY, I'D LIKE TO THINK THAT, GIVEN

THE CIRCUMSTANCES

I HAVE BEEN EXTREMELY FORGIVING UP TO

NOW BUT THAT IS A HORRIBLE IDEA!

مارد وشوشني: شلبي كان من عيني بس رغم إني صهينت علي مصاييك كلها

لغاية دلؤتي بس دي بقي مش هعديها

The cultural interference here affects the target utterance positively. However, the adapter intentionally neglects the form of the source. The target utterance would be completely distorted if the form of the source was kept. The target utterance contains many cultural-based expressions out of the Egyptian dialect such as 'كان من عيني' /kaan min ؟yny/ (means I wish I could do that thing for someone), 'صعينت /sahynt/ (means acting like not conscious of what is happening around you) and 'مش هعديها' /miš ha؟dyhaa/ (means something that cannot be passed easily). After comparing these Egyptian Arabic expressions with that of the source, it can be noticed that the source utterance is converted into a target one that contextually and culturally fits the target audiences more than the one used in the source. In addition, the communicative purpose of the source situation is preserved in the target to a great extent. 


\title{
4.2.2. Creation
}

\section{Example 3}

Sullivan: I'm not even breaking a sweat.

\section{شلبي سلفان: لسةقمتعبتش}

Here, the example entails an English idiom 'breaking a sweet'. It is not rendered literally. The translator uses the creation procedure for replacing it in the target with an informal equivalent that matches the sense of the source.

\subsubsection{Exoticism}

\section{Example 38}

Example 4

\section{BIG EYE:AH, NUTS.}

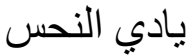

The translator employs the procedure for exoticism by which slang words are substituted by rough equivalents. 'Nuts' is an informal expression used frequently in spoken language. Additionally, it has many connotations. The translator's choice 'النحس' /ilnahs/ is roughly the closest to describe the situation displayed on the screen. To clarify, Big Eye is someone who met James Sullivan and Mike Wazowskion the street holding a newspaper and getting fire out of his mouth that caused the newspaper to be burnt. 


\section{Conclusion}

The findings show that the dubbed version seems more humorous than the source one due to the expressive nature of the Egyptian dialect that has been seen in its huge entity of idiomatic expressions. Moreover, evaluating translation as being successful is based on the reception of the target text as though it was original not a translation; this is what could be felt while watching the Egyptian Arabic dubbed version of Monsters, Inc. In other words, the utilization of a vast number of idiomatic expressions and culture-bound terms specific to the Egyptian dialect helped enhance the enjoyment of the movie and familiarizing the target text to its recipients.

The present research is centered on the procedures for adaptation on which the researcher depends in analyzing the selected data. So, cultural and situational adequacy alongside creation are the most frequently used procedures for the treatment of these references. Transcription of the original and omission are used in some cases. Expansion is rarely used because of the technical constraints of the dubbing process, including time restriction and synchronization, which requires adjusting the movements of the actor's mouths with what appears on the screen. 


\section{References}

Bassnett, S. (2002). Translation Studies ( $3^{\text {rd }}$ Ed.). London \&New York: Routlegde.

Bastin, G. (2009). Adaptation. In M.Baker\&G.Saldanha

(Eds.). Routledge Encyclopedia of Translation Studies. $\left(2^{\text {nd }}\right.$

Edition). (pp. 3-5). London: Routledge.

Bastin, G. (2015). Adaptation and the paramount communication strategy. Linguaculture: The Journal of

Linguaculture Centre for intercultural and Interlingual Research, 2014(1), 73-87.

House, J. (2009). Translation. Oxford: Oxford University Press.

Nida, E. \& Taber, C. (1982). The Theory and Practice of

Translation.

Leiden: E. J. Brill

Sanders, J. (2006). Adaptation and Appropriation. London and New York: Routledge. 